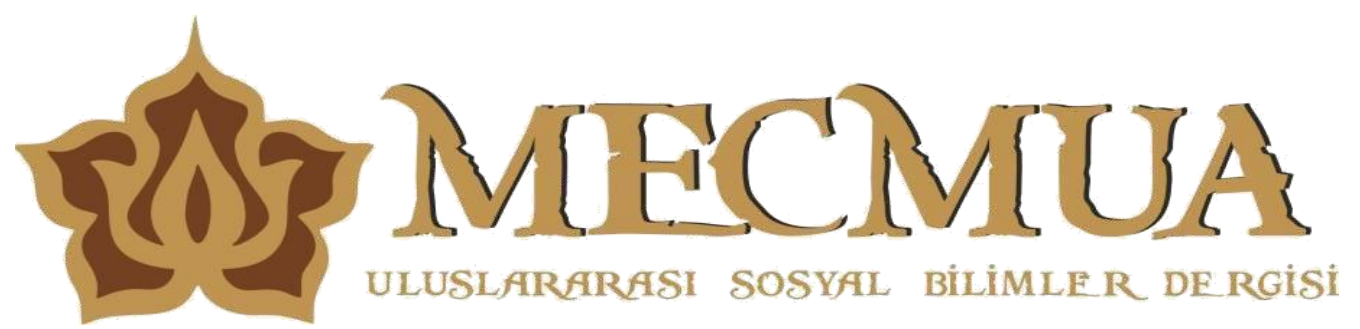

Mecmua Uluslararasi Sosyal Bilimler Dergisi [International Journal Of Social Sciences] Uluslararası Hakemli E-Dergi/ Referee International E-Journal

Yil: 6, Sayı: 11, ISSN:2587-1811 Yayımlanma Tarihi: 30.03.2021

Pandemi Sürecinin Sosyolojik Etkileri Üzerine Bir İnceleme: Londra Cezire Derneği
A Study on the Sociological Effects of the Pandemia Process: Jazeera Association of London

\title{
İsmail SEZGIN
}

ID Milli Eğitim Bakanlığı, Öğretmen, Doktora Öğrencisi, Mersin, Türkiye. sezgin1571@hotmail.com

\section{Makale Bilgisi / Article Information}

Makale Türü: Araştırma Makalesi

DOI: mecmua. 828596

Yükleme Tarihi: 19.11.2020

Kabul Tarihi: 09.01.2021

Yayımlanma Tarihi: 30.03 .2021

Sayı: 11

Sayfa: $501-518$
Article Information: Research Article

DOI: mecmua. 828596

Received Date: 19.11.2020

Accepted Date: 09.01.2021

Date Published: 30.03.2021

Volume: 11

Sayfa: $501-518$

\section{Atıf / Citation}

SEZGİN, İ. (2021). Pandemi Sürecinin Sosyolojik Etkileri Üzerine Bir İnceleme: Londra Cezire Derneği. MECMUA - Uluslararası Sosyal Bilimler Dergisi ISSN: 2587-1811 Y11: 6, Say1: 11, Sayfa: 501-518

SEZGiN, I. (2021). A Study on the Sociological Effects of the Pandemia Process: Jazeera Association of London. MECMUA - International Journal Of Social Sciences ISSN: 2587-1811 Year: 6, Volume: 11, Page: 501-518 


\title{
İsmail SEZGIN
}

\section{PANDEMI SÜRECININ SOSYOLOJIK ETKILERI ÜZERINE BIR İNCELEME: LONDRA CEZIRE DERNEĞi}

\author{
A Study on the Sociological Effects of the Pandemia Process: Jazeera Association of \\ London
}

\begin{abstract}
ÖZ
Bu çalışma Londra'da faaliyet gösteren Kıbrıslı Türklere ait Cezire Derneği'nin pandemi sürecindeki etkinliklerini incelemektedir. Kıbrıslı Türkler Birleşik Krallık'ta yaşayan Türkçe konuşan topluluk içerisinde en eski alt grubu oluşturmaktadır. Lozan anlaşmasından beri Birleşik Krallık vatandaşı olan Kıbrıslı Türkler 1960’lı yıllarda ülkenin başkenti Londra'ya kitlesel göç hareketleri gerçekleştirmiştir. Hem Kıbrıs'taki hem de diasporadaki Kıbrıslı Türkler birtakım faktörlerin etkisiyle seküler bir yaşam sürmektedir. Bu çalışmanın amacı seküler bir hayat tarzına sahip Kıbrıslı Türklerde yaşanan dini sosyal hareketliliği keşfetmektir. Cezire Derneği, Londra doğumlu Kıbrıslı Türk üçüncü nesil tarafindan kurulmuş bir dernektir. Dernek Kıbrıslı Türklere ait tarihi ve kültürel değerleri ortaya çıkarmaktadır. $\mathrm{Bu}$ değerleri ortaya çıkarırken de Kıbrıslı Müslüman Türk kimliğini ön planda tutmaktadır. Bunları gerçekleştirirken de bir takım sıkıntılara maruz kalmaktadır. Tamamen gönüllülerden oluşan bu ekip modern hayatın getirisi olan seküler nitelikli kimliksizleşmeye karşı projeler üretmektedir. Yaptıkları faaliyetlerle de İngiltere'deki Türk medyasında görünür hale gelmektedir. Bu çalışma, Londra'da yaşayan Kıbrıslı Türkler arasında gerçekleşen dini sosyal hareketliliği ölçmek için yapılmış nitel desenli bir saha araştırmasıdır. Elde edilen sonuçlar zamanın ve mekânın akışkanlaştığı bir dönemde, siber uzamda yapılmış mülakat görüşmelerinin verilerine dayanmaktadır.
\end{abstract}

Anahtar Kelimeler: Din sosyolojisi, Cezire Derneği, Dini Gruplar, Dini Kimlik, Covid-19 Pandemisi.

\begin{abstract}
This study is examining the activities of the Turkish Cypriot Jazeera Association, operating in London, during the pandemic process. Turkish Cypriots constitute the oldest subgroup of the Turkish speaking community living in the UK. Turkish Cypriots, who have been citizens of the United Kingdom since the Lausanne Agreement, carried out mass immigration to London, the capital of the country, in the 1960s. Turkish Cypriots both in Cyprus and in the diaspora, they lead a secular life due to some factors. The aim of this study is to explore the religious social mobility experienced by Turkish Cypriots who have a secular lifestyle. Jazeera Association is an association founded by the third generation of Turkish Cypriots born in London. The association reveals the historical and cultural values of Turkish Cypriots. When revealing these values, it prioritizes the Turkish Cypriot Muslim identity. While performing these, it is exposed to some difficulties. This team, consisting entirely of volunteers, produces projects against secular deidentification, which is the result of modern life. With their activities, they become visible in the Turkish media in England. This study is a qualitative patterned field study conducted to measure religious social mobility among Turkish Cypriots living in London. The results obtained are based on the data of the interviews conducted in cyberspace in a period where time and space are fluidizing..
\end{abstract}

Keywords: Sociology of Religion, Jazeera Association, Religious Groups, Religious Identity, Covid-19 Pandemic. 


\section{Giriş}

İnsan, diğer varlıklarla etkileşim içinde olan sosyal bir varlıktır. Doğup büyüdüğü toplum içerisinde sosyalleşir, anlam kazanır. Tek başına yaşamak mümkün olsa da hayatın zorluklarını paylaşmak ortaklaşa bir eylemi gerektirir. Soyun sürdürülmesi, insan varlığının devamı, eğitim, alışveriş vb. ihtiyaçlar insanı diğer insanlarla muhatap kılar. Tabii bu karşılıklı ilişkiyi düzenleyen bir takım yazılı ve yazısız kanunlar vardır. Anayasa, töre, kültür, ahlak, din, gelenek ve görenek gibi kural koyucular etrafında şekillenen insan, doğup büyüdüğü toplumun davranış örüntülerini öğrenir ve sosyal hayatta uygulamaya koyar.

Kıbrıs'ın Süveyş Kanalına yakın oluşu İngilizlerin bu adaya ilgisini artıırmıştır. 1878 yılında şartların da olgunlaşmasıyla İngiltere adayı Osmanlı'dan kiralamıştır. Elbette bu durum herhangi bir tarım arazisini kiralamak ile eş değer değildir. Adanın düzeni, hukuku, dili ve bunun gibi sistemin birçok parçası değişmek mecburiyetinde kalmıştır. Adanın ilhakı ile de Kıbrıs fiili olarak İngiliz kolonisine dönüşmüştür. Zamanla Kıbrıslı Türkler İngiliz vatandaşı olarak Birleşik Krallık'ın farklı vilayetlerine göç etmiştir. Esas göç ise 1960'lı yıllardan itibaren yaşanmıştır. $\mathrm{Bu}$ tarihten sonra özellikle Londra Kıbrıslı Türklere ev sahipliği yapmaya başlamıştır. $\mathrm{Bu}$ göçü hızlandıran en önemli etken ise adada yaşanan etnik çatışmalardır. Geçen onca yıldan sonra Britanyalı Türklerden söz etmek mümkündür.

$\mathrm{Bu}$ araştırmanın amacı modernliğin ve sekülerliğin getirdiği dezavantajlarla yoğrulmuş ve Londra'da ikamet eden Kıbrıslı Türklerde yaşanan dini sosyal hareketliliği incelemektir. Her ne kadar dernek yöneticileri derneğin dini kimliğini daha çok kişiye ulaşabilmek adına ön plana çıkarmasa da yaptıkları faaliyetlerde dini duyguların ve dini hassasiyetlerin varlığı ortadadır. İlerleyen bölümlerde bu konuya daha ayrıntılı değinilecektir. Böyle bir araştırmayı başlatan temel sebep, derneğin, Kıbrıs'taki Kanal T'de yapmış olduğu bayram özel televizyon programidir. Bu tarz tele programlar vesilesiyle dernek, Londra'da ve de Kıbris'ta yaşayanlar tarafindan bilinir hale gelmektedir. Bununla birlikte hem Kibrislı hem de din sosyolojisi öğrencisi olmam da konuya olan ilgimi arttırmıştır. Bu araştırma, üyesi olduğum toplumun sosyo-dini davranış örüntülerini keşfetmek için yapılmıştır.

"Londra'da yaşayan Kıbrıslı Türklerin dini sosyalleşmelerinde Cezire Derneği'nin rolü nedir?" sorusu araştırmanın temellendirilmesindeki problemin merkezini oluşturmuş̧tur. Nitel bir araştırma olan bu çalışmada kartopu örnekleme tekniği kullanılmıştır. Bu çalışma yapıldığı dönem itibariyle dünyada yaşanan Covid-19 salgınına denk gelmiştir. Küresel pandemi haline dönüşen virüs nedeniyle seyahat etmek elbette mümkün değildir. Bu yüzden yaptığımız bu çalışma, Londra-Mersin arasında zamanın ve mekânın uzamsal hale geldiği siber evrende etnografik bir alan çalışmasıdır. Bauman'ın perspektifinden bakılınca bu durum, modernite karşısında zamanın ve mekânın akışkanlığ 26). Zamanın, mekânın, bedenin vb. birçok katı unsurun akışkanlaştığı bir dönemde saha çalışmaları da bundan nasibini almaktadır. Dijital ortamlarda gerçekleşen etnografya çalışmalarına; sanal etnografya, siber etnografi, netnografya, online etnografya, bağlantılı etnografya gibi isimlendirmeler yapılmaktadır (Dereli, 2018: 131). Çalışmaya konu olan derneğin sanal ortamda 
verdiği kültürel mücadeleler ve de pandemi sürecinde artarak devam eden dijital ortamdaki kültür faaliyetleri göz önüne alındığında siber etnografik bir çalışmanın gerekliliği anlamlı olmaktadır. Nitel yöntemin benimsendiği bu çalışmada verileri elde etmek için derinlemesine görüşme, siber etnografik gözlem, doküman incelemesi teknikleri kullanılmıştır.

Katılımcılar takma isimlerle anonimleştirilmiştir. İbrahim ve Adem takma isimli katılımcıların, bu çalışmayı gerçekleştiren araştırmacıyla Kıbrıs'a dayanan bir tanışıklı̆̆ bulunmaktadır. Araştırmacı bu çalışmaya başlamadan önce de derneğin faaliyetlerini takip eden birisidir. Ayrıca derneğin sosyal medya sayfalarını düzenli olarak takip etmektedir. Araştırmanın kilit katılımcısı Adem'dir. Adem'in aracılığıyla diğer katılımcılara ulaşılmıştır. Katılımcıların yaşadığı Londra şehri ile araştırmacının yaşadığı Mersin şehri arasında iki saatlik zaman farkı vardır. Katılımcılarla telefon üzerinden ön görüşme yapılmış, ardından belirlenen ortak bir zaman diliminde mülakat şeklinde gerçekleştirilmiştir. Sorulacak sorular hakkında katılımcılar önceden bilgilendirilmiş ve görüşme esnasında ek sorularla takviye edilmiştir. Katılımcıların önceden soruları bilmesi nedeniyle yapılan görüşmeler, yarı yapılandırılmış görüşme şeklindedir (Punch, 2005: 167). 2020 yılı Haziran ayı içerisinde farklı günlerde, örneklemi oluşturan katılımcılar ile Whatsapp programı üzerinden bire bir tele görüşme gerçekleştirilmiştir. Bilgilerin kalıcı olması için de görüşmeler esnasında önemli noktalar not edilmiştir. Bunun yanı sıra görüşmeler ikinci bir cihaz yardımıyla ses kaydına alınmıştır. Daha sonrasında ise deşifre işlemi gerçekleştirmiştir.

\section{A- Araştırmanın Teorik Çerçevesi}

İnsanın herhangi bir gruba ait olma isteğinin altında sosyo-psikolojik birtakım nedenler yatmaktadır. Mesela gruplaşma sonucunda ortaya çıkan kolektif güç, insana güven vermektedir (Dönmezer, 1994: 163). Kolektif gücü arzulayan gruplar, katılımcı sayısına göre küçük-büyük grup olarak ayrılabilir. Küçük gruplar mesleki, ailevi, spor, din, siyaset vb. maksatlarla bir araya gelmiş kişilerden oluşabilmektedir (Dönmezer, 1994: 186).

Fitcher'e göre grup yaşamının sürdürüldügü dört temel nokta şunlardır: Ortak geçmiş, ortaklaşa paylaşılan mekân, benzer bedensel özellikler ve ortak ilgiler. Modern, karmaşık ve büyük ölçekli toplumlarda, önemi azalsa bile, sosyal ilişkilerde ortak geçmişe dayanan gruplar en sağlam bağlara sahip olandır. Bu gruplar bazen 'kan grupları' olarak adlandırılmıştır (Fichter, 2011: 65-66).

Cooley tarafindan sosyolojiye kazandırılan birincil grup-ikincil grup ayrımına göre; birincil grup ortak faaliyetlerle ve duygusal bağlarla yoğun bir şekilde bağl1 olan gruptur. Ayrıca üyeler yüz yüze etkileşimi sağlar, üyeler arası ilişkiler duygu yüklü ve kapsamlıdır. Tonnies' in 'gemeinschaft' kavramına benzerlik gösterir. Bu grup genellikle aileyi ve küçük geleneksel cemaatleri içerir. İkincil grup ise Tonnies'in 'gesellschaft' kavramına yakınlık gösterir. İkincil gruplara örnek ise mesleki gruplar ve siyasi partiler vb. yapılardır. Bu grubun üyeleri arasında amaçlı özel ilişkiler ve araçsal olarak ilişkili bazı eylemler söz konusudur (Kirman, 2004: 93).

Hervieu-Leger'e göre büyüsü bozulmuş, anlamını yitirmiş toplumlar hızlı inanç patlamalarının yaşandığ 1 toplumlardır (Hervieu-Leger, 2009: 117). İnsanlar kendilerini daha az dindar olarak görüyorsa, bu olay sekülerliğe atıf değil, 
kendilerinden önceki nesillere olan bağl1lıklarını daha az hissetmeleri ile alakalıdır. Kişilerin geçmişe ait zincirleri dağılmıştır. Ancak dağılan parçalar bir araya tekrar getirilirse tekrardan aynı anlamı ifade edebilecektir. Hafiza zincirinin dağıldığ durumlarda ise toplumsal hafiza kaybı (amnesia) oluşacaktır (Şentürk, 2004: 104105). Dağılmış hafıza zincirlerinin tekrardan bir araya gelmesi için küçük anılara sarılmak, anıları yaşatmak etkilidir. Hervieu-Leger'e göre anıları ortaya çıkaracak iki grup etkinliği vardır: Küçük dini gruplara katılım ile mezhep veya tarikat olarak bir araya gelen insanların oluşturduğu gruplara katılım. Küçük dini gruplara katılan insanlar gönüllü kardeşlik bağı oluştururlar. Kolektif bir söyleme sahip olan bu insanlar, isteyerek bir araya gelirler ve böylelikle de anlamını yitiren sosyal gruplar daha bir anlamlı hale gelmeye başlar. Kendi ailelerinden veya yakınlarından olmayan insanlarla bir araya gelerek gönüllülük esasında bir dini beraberlik oluştururlar (Hervieu-Leger, 2009: 120-124).

Bu bilgiler 1şığında sosyolojik açıdan değerlendirildiğinde Cezire Derneği birincil küçük grup görünümündedir. Derneğin temel amacı öncelikle Kıbrıslı Türklere ulaşmaktır. Cezire Derneği adında bir ihtiyacın varoluşu bir bakıma asabiyet olduğu da söylenebilir. Asabiyet, bir nesilden gelenlerin ortak idealler etrafinda kümelendiği ve birlik olmanın neticesinde kuvvet, kudret ve üstünlük elde etmelerine denir (Kirman, 2004: 26). Asabiyet kavramının fikir babas1 İbn Haldun'a göre asabiyet, sadece nesep birliğinden veya ona benzer bir şeyden hâsıl olur (İbn Haldun, 2018: 334). Belli bir soya hizmet etme düşüncesi İbn Haldun'un deyimiyle Londra'daki Kıbrıslıların asabiyet sahibi olduğunun göstergesidir. Belli bir amaç etrafına toplanmış bu insanların, toplumsal hafıza kaybına uğramamak ya da anomiye karşı birlik oluşturabilmek adına Cezire Derneği'ni kurdukları söylenebilir.

\section{İngiltere'deki Türkler}

Rusya sıcak sulara inme ve Panslavizm politikası nedeniyle sürekli Osmanlı'yı tehdit ediyor, bir yandan da azınlıkları isyana teşvik ediyordu. Osmanlı-Rus Harbinden sonra Balkanlar üzerinden Yeşilköy'e (Ayastefanos'a) kadar gelen Ruslar, aynı zamanda Doğu Anadolu'da başarı sağlamış ve Osmanlı'yı sıkıştırmıştı. 1878 yılında patlak veren Osmanl1-Rus Harbi esnasında Osmanlı Devleti artık zayıflamış ve iyice borca girmişti. İngilizler de bunu firsat bilip Rus politikalarına karşı Osmanlı'yı koruyacaklarına söz verdiler ve Kıbrıs'1 Süveyş Kanalı'nı idare edebilmek için kiralamak istediler. Anlaşmaya göre Ruslar Batum'dan, Kars'tan, Ardahan'dan çekildiği takdirde İngilizler de Kıbrıs'1 geri verecektiler. Daha sonrasında İngiltere'nin itirazı üzerine Berlin Antlaşması imzalanarak Ruslar geri çekilmek zorunda kaldılar. İngiltere de destek karşıllı̆̆ında istediği ve sömürgelerine gidebilmek için bir karakol mesafesinde olan Kıbrıs'a bir komiser vali yolladı. Meclis-i Kavanin (kanunlar meclisi) oluşturularak adanın yönetimi, başkanı İngiliz olan bir konseye devredildi (Ateşin, 1996: 95-110). Ada hukuken olmasa da fiilen İngiltere'nin yönetimi altına girdi. I. Dünya Savaşı'nda Osmanlı Almanya'nın yanında yer alınca, karşı tarafta olan İngiltere, Kıbrıs'ı ilhak ettiğini duyurdu ve 1923 yılına kadar adayı zorla elinde tuttu. 1923 Lozan Anlaşmasıyla da Kıbrıs İngilizlerin toprağı olarak kabul edilince resmi olarak adada Britanya İdaresi başlamış oldu. Türklerden gitmek isteyenlere izin verildi ya da kalmak isteyenlere de İngiliz pasaportuna geçme hakkı tanındı. Yeni bir göç dalgasıyla da Türkler adadan çekilmeye başladılar. Ayrıca Türkiye Cumhuriyeti Larnaka Konsolosu 
olarak görev yapan Asaf Bey'in de çabalarıla Kıbrıs'tan gitmek isteyenlere yardımcı olunmaktaydı (Ateşin, 1996: 166).

Kıbrıslı Türkler 1950'lilerde artan ve 1960'lı yıllarda doruğa ulaşan Kıbrıs'taki iç karıșıklıklar nedeniyle bașta İngiltere olmak üzere Avustralya, ABD, Kanada gibi ülkelere göç etmiştir. Kıbrıslı Türklerin Avrupa Kıtası'nda Türkiyeli göçmenlerden daha fazla olduğu tek yer İngiltere'dir. Türkçe konuşan topluluğun (Kıbrıslı Türkler, Türkiyeli Türkler ve Kürtler) en eski alt grubunu Kıbrıslı Türkler oluşturmaktadır (Atay, 2006: 31; Coştu, 2018: 86). Londra' daki Türkler arasındaki ilk sivil toplum hareketlerinin öncüsü de Kıbrıslı Türklerdir. 1951 yılında Londra Kıbrıs Türk Cemiyeti ise Türkler tarafından kurulan ilk cemiyettir. Türk Müslümanları arasında örgütlenme faaliyetlerinin de Şeyh Nazım Kıbrısi'nin önderliğinde yapıldığı görülmektedir. 1970'li yıllardan beri Şeyh Nazım Londra'ya İslami faaliyetler için gidip gelmiştir.

2011 yılında yapılan nüfus sayımına göre Birleşik Krallıkta bulunan 2,6 milyon Müslüman nüfus, ülke nüfusunun $\% 5$ 'ine tekabül etmektedir. Ülkede bulunan Müslümanların \%68'ini Asya kökenliler; \%10'unu Afrika kökenliler; \%15'ini ise Ortadoğu kökenliler, Doğu Avrupa kökenliler ile Türkiyeli ve Kıbrıslı Türkler oluşturmaktadır. Müslümanların \%8'ini ise İngiliz Müslümanlar (Galli, İskoç, İngiliz, İrlandalı) oluşturmaktadır. (Coştu, 2018: 28-32)

Etnik ve coğrafi hassasiyetlerden ötürü İngiltere'de yaşayan Kıbrıslı Türkleri, Türkiyeli Türkleri ve Türkiyeli Kürtleri tanımlamak için en kapsamlı ifade 'Türkçe konuşan topluluklar' ifadesidir (Atay, 2006; Coştu, 2018). Kıbrıslı Türklerin nüfusu tam olarak saptanabilmiş değildir. Bu durumun bir takım siyasi ve sosyolojik mazeretleri vardır. Aynı problem Kuzey Kıbrıs Türk Cumhuriyeti nüfusunun belirlenmesinde de görülmektedir. KKTC'de en kapsamlı nüfus sayımı 2011 'de yapılmış olmasına rağmen günümüzde KKTC nüfusu ile alakalı güncel tartışmalar varlığını sürdürmektedir.

\section{Cezire Derneği Hakkında Bilgiler}

Cezire Derneği hakkında bilgi vermeden önce Londra'daki Türklere ait kurum ve kuruluşlara değinmekte yarar vardır. Resmi bir hüviyete sahip olan KKTC Londra Temsilciliği, 1963-64 yılları arasında Kıbrıs Türk Cemaat Bürosu olarak faaliyetlere başlamıştır. 1975 yılında Kıbrıs Türk Federe Devleti'nin kurulmasıyla birlikte, Cemaat Bürosu, Kıbrıs Türk Federe Devleti Temsilciliği olarak faaliyet göstermeye başlamıştır. 1983 yılında KKTC'nin ilan edilmesinin ardından ise temsilcilik, KKTC Londra Temsilciliği olan şimdiki ismini almıştır. KKTC Londra Temsilciliği, KKTC hukuken tanınmadığ 1 için temsilcilik olarak isimlendirilmektedir. Londra' daki temsilciliğin işleyişi ise daha çok büyükelçilik gibidir (KKTC Londra Temsilciliği, t.y. ).

Daha önce de değinildiği gibi 1951 yılında kurulun Kıbrıs Türk Cemiyeti, Londra'da Türkler tarafindan kurulan ilk toplumsal organizasyondur (Uysal, 2016: 433). Ayrıca Müslüman Türkler adına dini örgütlenmenin ilk örneği ise AlHaqqani Trust'ın bünyesinde bulunan Şeyh Nazım El-hakkani Dergâhı'dır. Adından da anlaşıldığı gibi Kıbrıslı Nakşibendiyye Şeyhi Mehmet Nazım Adil ElKıbrısi (1922-2014)'nin öncülüğünü yaptığı bir dini kurumdur (Coştu, 2018: 114 119). 
Londra'daki Kıbrıslı Türklere, Türkiyeli Türklere ve Kürtlere ait organizasyonlar oldukça heterojendir. Bunun başlıca nedeni topluluklar arasındaki etnik, ideolojik ve kültürel farklılıklardır. Türkiye ve KKTC'deki meseleler Londra'daki kuruluşlara da yansımıştır. Londra'da birçok dernek, vakıf ve kültür merkezini bünyesinde barındıran üç çatı kuruluş vardır. Bunlar İngiltere Kıbrıs Türk Dernekleri Konseyi, İngiltere Türk Dernekleri Federasyonu ve Demokratik Güç Birliği Platformu'dur (Uysal, 2016: 432-433).

İngiltere Kıbrıs Türk Dernekleri Konseyi'ne bağlı toplam 23 dernek vardır. Cezire Derneği de bu konseye bağlıdır (Uysal, 2016: 434). Konsey içindeki dernekleri kabaca tasnif etmek gerekirse: Bunlar hemşeri dernekleri, diasporik-tarihi dernekler, folklorik-kültürel dernekler ve Kıbrıslı Türk okullarıdır. Cezire Derneği de Kıbrıs tarihini ve kimliğini tanıtmayı misyon edinmiş tarihi-diasporik bir görünüme sahiptir.

Kaynak kişilerde Adem'in verdiği bilgilere göre dernek 2008 yılında kurulmuştur. İlk ismi ise 'Kıbrıs Türk Mirasına Hizmet Derneği' idi. Dernek isminin uzun olması ve akılda tutmak zor olduğu için 2011 yılında şimdiki ismini almıştır. Cezire Derneği adını Osmanlıca ada manasına gelen 'cezire/jazeera' kelimesinden almıştır (Devellioğlu, 2008: 139). Tarihi vesikalarda Kıbrıs Adası'na Cezire-i Kıbrıs (Kıbrıs Adası) denirdi. Bu sebeple akılda kalıcılığı kolay olması için bu isim verilmiştir. İsmin manası ve özellikle Osmanlıca bir kelime seçilmiş olması manidardır. Çelik'e (2017: 72) göre yabancısı olunan bir coğrafya, benimsenen bir isimle hafıza sistemine bağlanır ve tarihi arka planda kimlik ve aidiyet sunan manaya dönüşür. Bunun yanında dini grup ve cemaatler, isimlerin ayırt edici sembolik boyutlarını öne çıkartarak, isimleri bir kimlik veya gösterge aracı olarak kullanmaktadır (Çelik, 2005: 31). Derneğin logosu ise sekiz köşeli Selçuklu yıldızı içerisinde yeşil renkli Kıbrıs Adası'dır.

Derneğin sitesine bakıldığında ilk göze çarpan 'Geçmişini bilmeyen, geleceğini savunamaz’ sloganıydı (Cezire Derneği, t.y.). Savunma yapmak bir şeyi müdafaa etmek yani korumaktır. Kaynak kişilerin ortak söylemlerinde de bu durum hissediliyordu. Yaptığımız görüşmede Adem 'Derneğimizin amacı tebliğ değil. Müslümanız, Kıbrıslıyız, Türk'üz' derken korunacak değerlerin Müslüman Kıbrıslı Türk'üne ait olduğu anlaşılmaktaydı. Derneğin internet sitesinde de 'Amacımız, Kıbrıslı Türklerin tarihini araştırarak eşsiz kültürel yönlerimizi canlandırmak ve temsil etmek suretiyle Kıbrıslı Türklerin eşsiz kimliğini korumaktır.' denilerek açıkça kimliğe vurgu yapılmıştır.

\section{B- Araştırmanın Bulguları}

Görüşmeler Haziran 2020 tarihinde farklı günlerde, bire bir Whatsapp programı üzerinden gerçekleştirilmiştir. Katılımcıların mahremiyetlerinin korunması açısından takma isimler kullanılmıştır. Çalışmaya dâhil edilen katılımcılar kartopu örnekleme tekniği ile belirlemiştir. Katılımcıların bilgileri ise şöyledir:

Tablo 1: Katılımcıların Özellikleri

\begin{tabular}{|c|c|c|c|c|c|c|}
\hline Ad & $\begin{array}{c}\text { Cinsiy } \\
\text { et }\end{array}$ & Meslek & Yaş & $\begin{array}{c}\text { Doğu } \\
\text { m yeri }\end{array}$ & $\begin{array}{c}\text { İngiltere' } \\
\text { ye ilk } \\
\text { yerleșen }\end{array}$ & $\begin{array}{c}\text { Dernekteki } \\
\text { Rolü }\end{array}$ \\
\hline
\end{tabular}




\begin{tabular}{|c|c|c|c|c|c|c|}
\hline Adem & Erkek & Eğitimci & $30-35$ & $\begin{array}{c}\text { Londr } \\
\mathrm{a}\end{array}$ & $\begin{array}{c}\text { Dede- } \\
\text { nene }\end{array}$ & $\begin{array}{c}\text { Yönetim } \\
\text { kademesinde }\end{array}$ \\
\hline $\begin{array}{c}\text { İbrahi } \\
\mathrm{m}\end{array}$ & Erkek & Gazeteci & $30-35$ & $\begin{array}{c}\text { Londr } \\
\mathrm{a}\end{array}$ & $\begin{array}{c}\text { Dede- } \\
\text { nene }\end{array}$ & $\begin{array}{c}\text { Yönetim } \\
\text { kademesinde }\end{array}$ \\
\hline Burak & Erkek & $\begin{array}{c}\text { Öğretme } \\
\mathrm{n}\end{array}$ & $35-40$ & $\begin{array}{c}\text { Londr } \\
\mathrm{a}\end{array}$ & $\begin{array}{c}\text { Anne- } \\
\text { baba }\end{array}$ & $\begin{array}{c}\text { Yönetim } \\
\text { kademesinde }\end{array}$ \\
\hline Harun & Erkek & Memur & $45-50$ & $\begin{array}{c}\text { Londr } \\
\mathrm{a}\end{array}$ & $\begin{array}{c}\text { Dede- } \\
\text { nene }\end{array}$ & $\begin{array}{c}\text { Kardeş derneğin } \\
\text { yönetim } \\
\text { kademesinde, } \\
\text { paydaş }\end{array}$ \\
\hline $\begin{array}{c}\text { Zeyne } \\
\text { p }\end{array}$ & Kadın & $\begin{array}{c}\text { Halkla } \\
\text { ilişkiler } \\
\text { danışman } \\
1\end{array}$ & $45-50$ & $\begin{array}{c}\text { Londr } \\
\text { a }\end{array}$ & $\begin{array}{c}\text { Dede- } \\
\text { nene }\end{array}$ & $\begin{array}{c}\text { Katılımc1, } \\
\text { paydaş }\end{array}$ \\
\hline
\end{tabular}

Görüşülen beş katılımcının üçü derneğin aktif yönetim kadrosundadır. Harun takma adlı görüşmeci ise Kıbrıs İslam Cemiyeti-Al Hashim Trust adlı cemiyetin yönetim kademesindedir. Diğer beşinci katılımcı ise Zeynep’tir. Zeynep Hanım derneğin yapmış olduğu seminerlere ara sıra katılım sağlayan ancak derneğin yönetimiyle alakası olmayan, dışarıdan birisidir. Ayrıca İngiltere'de yayın yapan T-wine dergisinin sahibidir. Harun ve Zeynep ikisi de Cezire Derneği'nin yönetim şemasında yer almasa da verdikleri destek ile dernekteki rolleri yukarıdaki tabloda paydaş olarak belirtilmiştir. Tabloya baktığımız zaman görüşmecilerin hepsi Londra doğumludur. İngiltere'ye ilk yerleşme durumuna baktığımızda, Burak hariç diğerlerinin dedesi-nenesi ilk göçen neslin içindedir. Katılımcılar Londra'daki ikinci ve üçüncü nesli oluşturmaktadır. Yaşları göz önüne alındığında, katılımcıların çocukları ise dördüncü nesli oluşturacaktır.

\section{Derdimiz Lobicilik Değil}

Londra'daki dernekler birbirlerinden farklı amaçlar doğrultusunda oluşmuştur. Cezire Derneği de Kıbrıslı Türklerin tarihini, kültürü, örfünü tanıtmak amacıyla kurulmuştur. Adem'in ve İbrahim'in üzerine basa basa söyledikleri cümle 'derdimiz lobicilik değildir'. Onlara göre lobicilik KKTC'nin uluslararası arenada tanıtılma mücadelesidir. Aktardıkları bilgilere göre onların asıl amacı KKTC'yi tanıtmak değildir. Amaçları ise yurtdışında yaşayan özellikle Londra'da yaşayan Kıbrıs Türklerine kendi tarihi mirasını tanıtmaktır. Özelde ise neredeyse Türkçe konuşamayan, örfünü, kültürünü tanımayan Kıbrıslı Türk gençlerine, gidecek bir kapı oluşturmanın derdindeler. Adem adada '1400 yıllık tarihimizi tanıtmak' derken Hz. Osman'ın halifeliği döneminde başlayan sahabe akınlarına dikkat çekmektedir. Ona göre Kıbrıs'taki Müslüman Türk tarihini anlatırken yakın tarihe ağırlık verilmesi neticesinde Türkler adada misafir ya da yabancı pozisyonuna düşmektedir.

Derneğin hitap ettiği esas kitle Kıbrıslı Türklerdir. Diğer milletlerden katılımcılar zaman zaman olsa da büyük çoğunluğu Kıbrıslı Türkler oluşturmaktadır. İbrahim'e göre esas kitle genelde dünyadaki tüm Kıbrıslı Türkler, özelde ise Kıbrıs'ta yaşayanlardır. 'Çünkü Kıbrıs'ta kimlik korunmazsa diaspora olmayacak' diyerek 
haklı endişelerini dile getirmektedir. Adem ise bu minvalde 'Geçmişi anlamak için dinimizi unutmamız gerekir’ diyerek dine vurgu yapmaktadır.

Burak yaptıkları çalışmaları 'asimile olmamak' adına yaptığını söylerken 'kültürümüzü, dinimizi, örfümüzü, tarihimizi tanıtmak' diye devam etmektedir. İbrahim'in düşüncesine göre ilk gelenler kimliksel değerlerin farkındadır. Ancak 90'larda ve sonrasında doğanlar daha hızlı asimile olmaktadır. Ortak başka bir kanı ise gençlerin arayışta olduklarıdır. İbrahim bu konuda 'İslam'ı öğrenip bizle irtibat kuranlar oluyor. Aynı zamanda bizi öğrenip İslam'ı merak edenler oluyor' diyerek Müslüman ve Kıbrıslı Türk kimliğine işaret etmektedir. Zeynep ise gençleri tecrübesiz olarak nitelendiriyor. Zeynep'e göre danışacak kimsesi olmayan gençler fundamentalistlerle tanışıyor ve Batı'ya karşı kışkırtılıyorlar. Zeynep bu yüzden Cezire Derneği’nin varlığını önemli bulmaktadır. Ona göre Cezire Derneği’ndeki kişilerin evrensel dili bilmesi, İngilizce konuşmaları, kendi kültürlerini tanımaları çok önemlidir. Bu özelliklerinden dolayı dernek, gençlerle değerler arasında köprü görevi görmektedir.

Derneğin çalışma stili ise daha çok akademik çalışmalardır. Konferans, söyleşi, tv programları, sosyal medya platformlarında etkinlik, makale ve bildiri yayınlama vb. çalışmalardan bahsetmek mümkündür. Dernek ile bağlantısı bazı konferanslara katılmak olan Zeynep, konferanslarda duyduğu bilgiler karşısındaki hayretini 'Waow oldum' diyerek belirtmiştir. Ona göre yeni nesil bu bilgilere açtır. Duyacak başka yerleri de yoktur.

Adem yaptığı tarihi çalışmalarda birincil kaynaklara ulaşmanın gerekliliği üzerinde 1srarla durmaktadır. Ona göre Kıbrıslı tarih kurumları Osmanlıca bilmemekte ve de batının öğrettiği tarihi oku(t)maktadır. Böyle bir durumda şarkiyatçıların kullandığ 1 islamofobik terimler kullanılmaktadır. Mesela 'Arap akını diyorlar ama onların sahabe olduklarını söylemiyorlar' diyerek Kıbrıslı Türk tarih kitaplarındaki oryantalist islamofobik dili eleştirmektedir. Çalışmalarında İbn Kesir, Taberi, Buhari gibi İslami birincil kaynakları kullandığı ifade etmektedir. Adem'in aktardığı bilgiye göre panellere katılan az sayıdaki diğer Müslüman gruplardan ve daha sonra netten izleyenler arasından bazı kişiler, bu hassasiyetinden ötürü onunla hususi olarak iletişime geçip teşekkür ediyorlar. Ayrıca İbrahim'den edindiğim bilgiye göre Cezire Derneği yakında tarihi nitelikli bir eser ortaya koyacaktır.

Zeynep'in verdiği bilgilere göre özellikle solcu geçinen Kıbrıslı bir gürûh tarafindan Cezire Derneği kötülenmektedir. Aslında bu insanlar Türkiyelileri, siyahileri ve Müslüman Kıbrıslıları da kötülemektedir. Bunun yanı sıra Zeynep Kıbrıs'ta yaşanan İslam karşıtı olaylara ithafen 'Aynısı İngiltere'de olsa islamofobi olarak görünüp kınanırdı' demektedir. Bu duruma ek olarak Adem'in aktardığ 1 şu bilgiler de önemlidir. Eşi Kıbrıs doğumludur ve evlendikten sonra Londra'ya gelmiştir. Eşi Londra'daki manzarayı görünce 'Sanki bütün Kıbrıslı Müslümanlar burada toplanmış’ diyerek şaşkınlığını gizleyememiştir. Burak’tan edindiğim bilgilere göre gençlikte gözle görülür bir canlanma vardır. Geçmişte Kıbrıslı Türk cami yöneticisi yokken şimdilerde vardır. Her ne kadar İslami bir canlanmadan söz etmek mümkünse de Kıbrıslı Türklerin büyük bir kısmını kapsamadığını belirtmekte fayda vardir.

Görüştüğümüz dernek yöneticileri 1srarla lobicilik faaliyetleri olmadığını söylese de bu durum dişardan bakan bir gözle başka türlü görünebilir. Zeynep yapılan bu 
çalışmaları Kıbrıs Sorunu bağlamında da önemli bulmaktadır. Rumlar sürekli kuzeydeki Hristiyan mirasının yok olduğundan şikâyet etmektedir. Hâlbuki güneyde de benzer durumlar yaşanmaktadır. Ancak KKTC hükümetleri bu durumla pek alakadar değildir. Cezire Derneği ise güneyde yaşanan kültürel tahribatı raporlamak suretiyle uluslararası medyada ses getirmektedir. Zeynep'in dikkat çektiği bir başka husus ise kültürel transferlerdir. Geçenlerde yüz bin takipçisi olan Filistinli bir arkadaşı ve onun çevresi Diriliş Ertuğrul dizi setini ziyaret etmiştir. Eğer onlara adadaki Kıbrıslı Müslüman/Türk mirası tanıtılırsa bir sonraki gezilerini Hala Sultan Tekkesi’ne yapmaları mümkündür. Ona göre Cezire Derneği, Kıbrıs'ın İslami değerlerini diğer Müslüman gruplara anlatabilecek kapasitededir.

\section{Diğer Müslüman Topluklarla İlişkiler}

İngiltere'de yaşayan Müslümanlar etnik çeşitlilik açısından çok uluslu bir görünüme sahiptir. Birleşik Krallık'ın gütmüş olduğu eski kolonilerle iyi geçinme politikası bunda etkilidir. Okyanusya'dan Amerika'ya kadar irili ufaklı birçok eski koloni İngiliz Milletler Topluluğu (The Commonwealth Countries) üyesidir. II. Dünya Savaşı sonrasında ülkenin kalkınması için gerekli olan istihdam, bu topluluğa üye ülkeler arasından gerçekleşmiştir. Ayrıca Doğu Avrupa'da yaşanan Balkanizasyon süreci neticesinde yeni mülteci göçleri gerçekleşmiştir. Halen daha dünyanın birçok bölgesinden nitelikli mülteci kabul edilmektedir (Coştu, 2018: 2124).

Osmanlı'dan ayrıldıktan sonra Kıbrıslı Türkleri bekleyen bir takım sıkıntılar vardı. Kimliksel sıkıntıları tetikleyen elbette birçok faktör vardır. Bunların arasında dini alanda yaşanan sıkıntılar Kıbrıs'ta yaşayan Müslüman Türkler arasında her dönem belli aralıklarla günümüze dek devam etmiştir (Sezgin, 2019: 26-38). Haliyle bu sıkıntılar yurtdışına giden Kıbrıslı Türklerle birlikte yeni yerleşim yerine de taşınmıştır. 'Diğer Müslüman gruplar Kıbrıslıları nasıl görüyor?' diye sorduğumda Burak 'Bizi laik görüyorlar' demiştir. Adada oluşan Kıbrıslı Türk’e özgü seküler yaşam tarzı günümüze değin Londra'da varlığını hissettirerek devam etmektedir. Zeynep'in 'Kıbrıslılar bir yanda dua eder, diğer yanda rakı içer' sözü bu duruma örnek olabilmektedir. ${ }^{1}$ Harun'a göre kültürel farklılıklar olmakla birlikte diğer İslami gruplar camiye ve ibadete daha düş̌ündür. Diğer Müslüman topluluklarla bir arada yaşamak belli bir seviyede etkileşime neden olmaktadır. Adem'in ifadesiyle 'Kıbrıslılar diğer İslami grupları gözlemliyorlar ve neden biz oruç tutmuyoruz' diye kendilerine sormaktadır. Diğer dini grupları gözlemlemek suretiyle Kıbrıslı Türklerde İslam'a karşı merak oluşmaktadır. Ayrıca gruplar arasında dindarlık seviyesi farklıdır. İçki içmeyen biri Cezayirliler için normal biriyken Kıbrıslı Türkler açısından dindar sayılmaktadır. Yine buna benzer bir örnekte bir iki gün oruç tutmak Kıbrıslılar için dindarlık göstergesi olabilmektedir.

İbrahim 33 yaşında deneyimli bir gazetecidir. Geçtiğimiz dört y1l boyunca Trt World bünyesinde çalışmıştır. Bu sene ise 'radioeastmed.com' adlı kendi internet

1 Sezgin 2019 yılında KKTC Güzelyurt'ta yaptığı çalışmalarda benzer olgularla karşılaşmıştır. Örneğin, hiç dua etmediğini söyleyen ve kendini ateist olarak adlandıran bir katılımcı gayri ihtiyari dua cümleleri kullandığını ifade etmiştir. Ahiret inancı taşımayan bir başka katılımcı ise her gece dua edip şehadet getirmeden uyumadığını ifade etmiştir. Başka bir katılımcı ise içki masasından kalkarken bile şükrettiğini ifade etmiştir. Diğger bulgular için, bkz. (Sezgin, 2019). 
sitesini kurmuş, dernek çalışmalarına yoğunlaşmıştır. ${ }^{2}$ Geçmişte Batı Trakya'yı ziyaret eden İbrahim'e göre Batı Trakyalı Türkler, Kıbrıslı Türklere nazaran uluslararası medyada kendini tanıttırmış ve kabul ettirmiştir. Ümmetin diğer parçaları Kıbrıslı Müslüman Türk’ü tanımamaktadır. Kıbrıslı denilince akla Rum gelmektedir.

Londra'daki Türkçe konuşan topluluk açısından durum biraz daha farklıdır. Londra'da aynı mekânı paylaşan bu insanlar geçmiş ortak tarihleri ve ortak konuşulan dil sayesinde daha fazla etkileşim içerisindedir. Londra doğumlu, Türkçesi az, İngilizcesi iyi, birbirine benzeyen yeni nesiller arasında kimin Türk kimin Kürt ya da Kıbrıslı olduğunu dışarıdan bakan bir gözle ayırmak zordur. Adem bu konuda ortak geçmişin ve kültürün etkili olduğunu söylemektedir. Onları ayıran farklıklar diğer milletlerle kıyaslandığında kültürel olmaktan ziyade siyasi ayrımlar ve propagandalar gibi suni gündemlerdir. Tabii, görece kültürel farklı1ıklardan söz etmek mümkündür. Adem bu konu da şu açıklayıcı örneği sunmaktadır: 'Eskiden başörtülü Türk olduğu bilmezdim, ta ki Aksaraylılar veya Trabzonlular gelene kadar.'

Dini organizasyonlarda da bazı sıkıntılar görülmektedir. Adem'den edindiğim bilgilere göre Türkiyelilerin olduğu camilerde diğer milletler -Kıbrılılar dahilgörev alamamaktadır. Fakat Şeyh Nazım Dergâhı'nda baş imamın biri Arnavut ${ }^{3}$, diğeri siyahidir. Son olarak Şeyh Nazım Dergâhı ile Cezire Derneği arasında iyi ilişkiler vardır. Her iki grubun Kıbrıslı Müslüman Türk oluşu bu yakınlığ arttırmaktadır. Adem müritlerin derneği çok sevdiğini söylemektedir. Çünkü onlara göre dernek, Şeyh Nazım'ın yıllar evvel kendine vazife bildiği bir işi yapmaktadır. Adem'in bir müritten aktardığı bilgilerde, Şeyh Nazım'ın Londra'da iki amacı vardı: İngiliz Müslüman yetiştirmek ve Kıbrıslı Türklerin kimliğini korumak. Dernek Kıbrıslı Türklerin kimliğini korumayı amaçladığı için müritler tarafından çok sevilmektedir.

\section{Zuhuri Baba Tekkesi İçin Verilen Mücadele ve Ardından Gelen Şöhret}

2020 Haziran ayı içerisinde Güney Kıbrıs'taki iki cami kimlikleri bilinmeyen Rumlar tarafından hedef alındı. Kimliği belirsiz saldırganlar 1 Haziran sabahında

2 İbrahim'in anlattığı enteresan anekdotlardan biri gazeteciyken yapmış olduğu Giritli Müslümanlar haberidir. Güney Kıbrıs’ta Giritli Müslümanları ziyaret eden İbrahim, onların Girit-Yunan soylu Müslümanlar olduğunu söylemektedir. Adları Müslüman ismi ve soyadları Yunanca'dır. 'Bizimle ortak acıları, tecrübeleri ve hikâyeleri var' diyerek Kıbrıslı Müslüman Türklerle aslen Giritli olan Yunan Müslümanlarını birbirine benzetmektedir. Giritli Müslümanlar, Girit Osmanlı'nın elinden çıkınca o dönem Osmanlı toprağı olan Lübnan, Suriye ve Anadolu sahillerine yerleştirilmiştir. Osmanlı dağılınca da bu insanlar Suriyeli, Lübnanlı ve Türkiyeli olmuştur. Suriye iç savaşından önce Güney Kıbrıs Rum Yönetimi'ne çalışmaya gelen Giritli Müslümanlar vardır. Ancak GKRY ve Yunanistan’a asıl göç Suriye'de yaşanan çatışmalarla gerçekleşmiştir. Dedelerinden kalma tapularla Girit'e ulaşan bu insanlar Yunan Hükümeti'nden mallarının iadesini talep etmiştir. Onlara söylenen şey ise malları Ortodoks Kilisesi tarafından kilisenin zimmetine geçirildiğidir. Ayrıca bu Müslüman Giritliler, Yunan soylu sayılmamış ve Suriyeli mülteci kategorisinde kamplara yerleştirilmiştir. İbrahim GKRY'de yaptığı çalışma esnasında bu insanların Yunanca ve Arapça konuştuklarını söylemektedir. Öyle ki anlaşabilmek için tercüman bile tutmuştur. Haberin aslı için, bkz. T-wine, 2018.

${ }^{3}$ Adem, Arnavutların komünizm sonrası yaşantılarını Kıbrıslı Türkler benzetmektedir. 
Limasol'da bulunan Köprülü Hacı İbrahim Ağa Camii’ne molotofkokteyli ile saldırdılar. Caminin dış duvarına "Immigrants, Islam not welcome (Göçmenler ve İslam hoş gelmediniz)" şeklinde ötekileştirici bir yazı yazdılar. Bu yazı içerik olarak Müslüman Türkleri hedef almaktan ziyade artan mülteci Müslümanlarla ilișkili olduğu gözükmektedir. 7 Haziran 2020'de tam bir hafta sonra bu defa Larnaka'da bulunan Tuzla Camii'ne sabah erken saatlerinde Bizans-Rum Ortodoks bayrağını astılar. ${ }^{4} \mathrm{Bu}$ ve benzeri provokasyonlar zaman zaman gerçekleşmektedir.

Zuhuri Baba Tekkesi güneyde yer alan Larnaka ilçesindedir. Ada, de facto olarak ikiye bölünmüş olsa da güneydeki Türk-İslam eserlerinin kontrolü resmiyette Evkaf'ındır (Kıbrıs Türk Vakıflar İdaresi). Tekke, Osmanlı'nın adaya gelişiyle beraber yeniçeri-Bektaşi erenleri tarafindan inşa edilmiştir. Yeniçerilerin tasfiyesi ile de bir dönem kullanılmamıştır. 1864 yılında Sultan I. Abdulaziz döneminde yeniden restore edilmiş ve cami olarak kullanılmaya başlanmıştır. 1869 y1lında ise Nakşi tarikatına devredilmiştir (Maden, 2015: 92-94). Larnaka'daki Türklerin kuzeye göç etmeleriyle beraber bugün tekke ve çevresi atıl vaziyettedir. Hatta belediye tarafından avlusuna beton dökülmüş, otopark olarak kullanılmaktadır. 2020 y1lı Ocak ayında Larnaka Belediyesi tarafindan tekkede restorasyon çalışmaları yapılacağı açıklanmıştır. Ancak Müslüman Kıbrıslıları tedirgin eden tekkenin bir kısmı içkili mekâna veya bara çevrilecek olmasıydı. Bu olay bugün bile Türkiye medyasına veya internet arama motorlarına yansımamış bir olaydır. $\mathrm{Bu}$ haberden sonra Cezire Derneği change.org sitesinden imza kampanyası başlatmış ve birçok kimsenin bu olaydan haberdar olmasını sağlamıştır. 19 Şubat 2020 tarihinde ise belediye başkanı Andreas Vyras, Güney Kıbrıs müftülük temsilcisi Şakir Alemdar'ın da bulunduğu bir toplantı ile restorasyonu yeniden gözden geçirmiştir. Şüphesiz bu başarının en büyük mimarı güney müftüsü Şakir Alemdar'dır (Cezire Derneği, 2020).

Etkili bir propaganda neticesinde kısa sürede çözüme kavuşan bu olayın görünmeyen kahramanları ise Cezire Derneği'dir. Hem kuzeydeki hem güneydeki yetkililere durumun vahametini bildiren dilekçeler yazılmıştır. İnternetten başlatılan bu kampanya dünyanın birçok bölgesindeki Müslüman'a ulaşmıştır. Bu gayretlerinden ötürü Cezire Derneği medyada görünür hale gelmiş̦tir. Burak’a göre derneğin televizyonlarda boy göstermesi, Zuhuri Baba Tekkesi'ndeki mücadele ile başlamıştır. Bu olay ile kanalların dernekten haberi olmuştur. Zeynep de bu mücadelenin dernek tarafından iyi yürütüldügünden bahsetmektedir. Bu olay ile dernek rüştünü ispatlamış ve İngiltere Kıbrıs Türk Dernekleri Konseyi tarafından destek görmeye başlamıştır. Hem Kıbrıslı Türk olmaları hem de kapasite sahibi olmaları nedeniyle konsey dernekten gurur duymaya başlamıştır. Ayrıca sosyal medyada yürütülen bu kampanya ile 20-30 yaş arası gençlerin derneği tanımasına vesile olmuştur.

\footnotetext{
${ }^{4}$ Yaşayan bu olayları sadece mültecilerle ve Kıbrıslı Türklerle olan ilişkiye bağlamanın eksik olduğunu düşünüyorum. 2020 senesinde bölge ülkelerini ilgilendiren önemli başlıklardan biri de 'Mavi Vatan' teorisidir. Libya'da yaşanan iç savaş neticesinde Türkiye ile Libya Ulusal Mutabakat Hükümeti arasında imzalanan anlaşmaya göre ortak kara suları belirlenmiştir. Tabii bu süreç en fazla Türkiyesiz plan yapan Mısır, İsrail, GKRY, Yunanistan gibi ülkelerin işine gelmemiştir. Doğu Akdeniz'de yapılan stratejik hamlelerle aynı dönemde cami saldırılarının vuku bulması manidardır.
} 


\section{Sosyal Medyanın Gücü: Yerimiz Yok Ama Her Yerdeyiz}

Aktif bir ekibe sahip olan derneğin binası veya ofisi bulunmamaktadır. Burak'tan edindiğim bilgilere göre çatı üst örgüt olan İngiltere Kıbrıs Türk Dernekleri Konseyi'nin de kendine ait bir mekânı yoktur. Konsey KKTC yetkililerinden bina tahsis edilmesi yönünde uzun zamandır talepte bulunmaktadır.

Kaynak kişilerden edindiğim bilgilere göre derneğin faaliyetleri arasında Türk festivallerine katılmak, konferans-toplantı tertip etmek, makale-bildiri yayınlamak vb. işler bulunmaktadır. Kıbrıs Türklerine ait bir faaliyet gerçekleştirileceği zaman Türk medyasına haber verilmektedir. Ayrıca Türkçe konuşan topluluğun dışında Uygur Türkleri, Irak Türkmenleri gibi gruplara da haber verilmektedir. Mekânın olmayışı bir takım zorlukları da beraberinde getirmektedir. Kaynak kişilerden edindiğim bir başka bilgide dernek yetkilileri, kendilerine katılmaları veya gençlik kolları olarak hizmet vermeleri karşılığında sınırsız destek vaadiyle gelen örgütleri reddetmektedir. İbrahim bu konu hakkında 'Değerlerimiz satılık değil' diyerek cevap vermektedir. Bu bağımsızlık ideali onları resmi olarak devletin vakıf defterine kayıt olmalarını bile etkilemektedir. Vakıf defterine kayıt oldukları zaman devletten maddi yardım alabileceklerini bildikleri halde bağımsızlıktan ve ilkelerden taviz vermemek adına kayıt olmamaktadırlar. Yine de fiziki olarak kullanabilecekleri en uygun yer Kıbrıslıların daha yoğun kullandıkları, Birleşik Krallık Türk İslam Cemiyeti'ne bağlı olan Ramazan Cami'dir. Cami geçmişte, Türklerin yoğun yaşadığı Hackney'de eski bir sinagogdu. 1977 yılında Kıbrıslı Türk iş adamı Ramazan Güney tarafından satın alınan sinagog camiye çevrilmiştir. Önceleri Shacklewell Cami olarak adlandırılan cami 2008 yılında Ramazan-1 Şerif Cami olarak yeniden isimlendirilmiştir (Coştu, 2018: 122-125).

Birleşik Krallıkta Kıbrıslı Türk medyası göçün başlangıcıyla beraber var ola gelişmiştir. Toplum olarak varlığını duyurmak, genel haberler almak ve vermek için Kıbrıslı Türklere ait radyo, gazete, dergi imkânları vardır. Son zamanlarda bunlara ek olarak sosyal medya da eklenmiştir (Reyhanoğlu, 2014). Gökdemir'e göre iletişim araçları hatta sosyal medya, kültürel asimilasyonun hızının yavaşlatılmasına yardımcı olabilecek araçlardır (Gökdemir, 2006). Ayrıca web'in ortaya çıkmasıyla da bireylerin ve grupların siber uzam ortamında dini görünürlükleri artmış ve tele-varoluşları yoğunlaşmıştır (Dereli, 2019: 11).

Cezire Derneği'nin fiziki olarak mekânı olmasa da siber uzamda etkinlikleri artmaktadır. Cezire Derneği ve Kıbrıs İslam Cemiyeti ortaklaşa olarak Londra merkezli Eurogenç Tv'de ve Lefkoşa merkezli Kanal T'de programlar yapmaktadır. Zeynep'in sahibi olduğu T-wine dergisi gibi dergilerde de boy göstermektedir. Kendisi de gazeteci olan İbrahim'e göre derneğin on iki yıllık mazisinde ilk sekiz yıl kimsenin umrunda değildiler. Yukarıda da anlatılan Zuhuri Baba Tekkesi için yaptıkları kampanyalar, Türk-Anadolu festivallerine katılım, seminerler, makaleler vb. çalışmalar arttıkça derneğin tanınma oranı da artmıştır. Esas tanınma süreci ise Covid-19 pandemisinin olduğu 2020 senesidir. Dernek yetkilileri pandemi nedeniyle haftada iki kere televizyona çıkma imkânı bulmuştur. Ayrıca sosyal medyada on binlerce Kıbrıslının dâhil olduğu -dini amaçlarla kurulmamış seküler- sayfalarda (daha çok facebook üzerinden) canlı yayınlar tertiplemiştir. Cezire Derneği ve Kıbrıs İslam Cemiyeti üyeleri bahsi geçen tv kanallarında ve sosyal medyada Ramazan ayı boyunca her gün medya önüne 
çıkmıştır. Medyada ilgi çekmeleri neticesinde 'Sandık Hikâyeleri’ adıyla Kanal T ekranlarında her çarşamba yayınlanacak mutat bir program bile başlamıştır. İlk bölümü 10 Haziran'da yayınlanan programda mekân olarak da Ramazan Cami (Shacklewell Cami) kullanılmaktadır. Üstelik akşam haberlerinden hemen sonra 'prime time' denilen, televizyon yayınlarının en çok izlendiği zaman diliminde yayınlanmaktadır.

Cezire Derneği’ni siber uzam ortamında görünür k1lan en önemli faktörlerden biri de pandemi sürecidir. Zeynep bu durum hakkında şunları söylemektedir: 'Ölüm hak ve Allah'ı her zaman anarsın ama Covid döneminde art arda ölüm haberleri geliyor ve insanların dine ilgisini arttırıyor. Düşün evdesin sıkılıyorsun. Tüm kanallar aynı. Ve karşına farklı bir şey çıkıyor. İster istemez insanların dikkatini çekiyor'. Yine aynı minvalde İbrahim de şu sözleri aktarmaktadır: 'Covid zamanında popüler olduk. Ölüm onlara sorumluluklarını hatırlattı belki de. Ya da daha önceleri işleri yoğundu diye bizi fark etmediler ama şimdi evde bizi dinlemek için çok vakitleri var.' İngiltere pandemiyle mücadele konusunda en gevşek davranan ülkelerin başında gelmektedir. Öyle ki ülkenin başbakanı bile virüse kapılmıştır. Art arda gelen ölüm haberleri ile bir tanıdığın, akrabanın veya mahalledeki herhangi birinin öldüğünü duymak, insanı maneviyata sevk ettiği bu çalışmada göze çarpmaktadır. Pandemi süreci kısmen de olsa dini bir arayışı tetiklemiştir.

\section{Al Hashim Trust ile ilişkiler ve Covid-19'lu Cenazelerin Nakli}

Kaynak kişilerden olan Harun, Kıbrıs İslam Cemiyeti Al Hashim Trust'un yönetim kademesindedir. Kendini tanitırken ' 28 yıldır bu camiadayız.' diyerek söze başlamıştır. Tablo 1'e göre Harun'un asıl mesleği memurluktur. Ayrıca kendisi mevlithandır. Mevlithan olması ona toplum nazarında ayrı bir konum atfetmektedir. Kıbrıs Türkleri için mevlit, dindarlığın en önemli göstergelerinden biri olduğu düşünülmektedir. Öyle ki Avrupa'da yaşayan Kıbrıslı Türkler arasında bile ciddi bir konuma sahiptir (Coştu, 2018: 164).

Kıbrıs İslam Cemiyeti'nin yapmış olduğu çalışmalar arasında zekât, fitre ve adak toplamak vardır. Dernek bu yıl İngiltere dışında yedi ülkeye bu yardımları ulaştırmışıır. Harun Kıbrıs Türk toplumunun cenaze işlemleriyle yakından ilgilenmektedir. Cenaze namazlarında namazın önemini israrla anlattı̆̆ından bahsetmektedir. Pandemi sürecinde Ramazan ayı boyunca on binin üzerinde üyesi bulunan bir sayfada her gece siyer dersi işlediğinden bahsetmektedir. Harun'un toplumda dini bir imajı vardır. Cezire Derneği'nde aktif görevi ise yoktur. Kendilerini kardeş iki dernek olarak görmektedirler. Harun, Cezire Derneği'ne 'Halkın içinde tanınmış biriyim. Halk onları tanıyana kadar gelin beraber yapalım.' teklifini sunmuş ve çalışmalarını beraber yürütmektedirler. İki dernek geçmiş senelerde Ramazan'da iftar yemeği, kandillerde kandil yemeği vermiştir. Harun, Cezire Derneği'ndeki üyeleri 'kültürlü, eğitim görmüş arkadaşlar' olarak görmektedir. İbrahim ise Kıbrıs İslam Cemiyeti'ni kendilerinden farklı kılan şeyin ise dini hizmet, yardımseverlik ve tebliğ misyonu olduğunu söylemektedir. Harun'a göre Kıbrıs İslam Cemiyeti'nin amacı 'insanlarımıza İslam'ın beş temel esasını en güzel şekilde öğretmek’tir.

Zeynep, Harun'u İngiltere'ye uygun bir dini karakter olarak nitelendirmektedir. Ona göre Harun Şia, Sünni, Alevi ayrımı gözetmeden evrensel değerlere önem 
vermektedir. Hatta Hristiyan ve Yahudiler onunla bir araya gelse konuşacak bir şeyler bulmaktadır. Zeynep Londra'daki imamların evrensel dili kullanmadıklarından şikâyetçidir. Zeynep bu konuda "Yakınlarımdan birinin cenazesine katıldım. Orada hoca Türkçe ifadelerle cenazede bulunan gayrimüslimleri kast ederek diyor ki 'etrafımızdaki şeytanlar'. Yahu bu adamlar benim komşum, iş arkadaşım. Cenazemiz var diye gelmişler. Onlara böyle denir mi?" diyerek başından geçen bir olayı anlatmıştır.

Pandemi sürecinde Kıbrıs Türk toplumunun en acı tecrübesi cenazelerini KKTC'ye gönderememektir. Aralarında Covid-19 (corona virüsü) nedeniyle hayatını kaybetmiş 6 cenazenin de bulunduğu toplam 18 cenaze, iki ay kadar Ramazan Cami'nin morgunda bekletilmiştir. En sonunda iki ülke arasındaki diplomatik kriz çözülerek cenazeler uçakla KKTC'ye getirilmiştir (Kıbrıs Gazetesi, 2020). Bu olayın yakın takipçilerinden biri Harun'dur. Harun'un aktardığ 1 bilgilere göre İngiltere'de mezarlıklar özel mülkiyet ve belediye mezarlığ 1 olarak ikiye ayrılmaktadır. Ölen kişinin naaşı kırk senelik bir sözleşme ile o mezarlığa gömülmektedir. Kırk senelik anlaşma bitince yeni bir anlaşma gerekmektedir. Eğer ölünün çocukları, torunları veya yakınları yeni anlaşma için parayı ödenmezse mezar sökülüp yerine başka biri gömülmektedir. ${ }^{5}$ Kıbrıslı Türkler bu yüzden İslam toprağına veya aile büyüklerinin yanına gömülmek istemektedirler.

Cenazelerin hemen gömülmeyip yaklaşık iki ay morgda bekletilmesi Londra'da Türkler arasında huzursuzluk çıkarmıştır. Zeynep'ten edindiğim bilgilere göre cenaze mevzusunda diğer dini gruplar Kıbrıslıları kınamıştır. Zeynep ise bu konuda "İnsanlar bir yandan acı çekerken diğer hocalar da 'günah işliyorsunuz' diyerek insanların acılarını katladılar" diye düşünmektedir. Ayrıca 'Eğer hocalar, buna benzer durumlarda böyle yapmaya devam ederlerse Kıbris Türklerini nasıl kazanacaklar' diye sormaktadır. Yaşanan bu cenaze nakil krizi ile çoğunluğu seküler olan Kıbrıslı Türklerde defin işlemlerinin önemi bir kez daha gözler önüne serilmektedir.

\section{6. Özümüz Türk, Dilimiz İngilizce}

Bu çalışmada edindiğim bilgilere göre İngiltere'de şu an dördüncü ve beşinci kuşak Kıbrıslı Türkler yetişmektedir. Bu genç nesiller içerisinde özellikle 90'lı yıllardan sonra doğanlar İngiliz toplumuna daha hızlı adapte olmakta veya asimile olmaktadırlar. Kullandığımız dil, kültürün en önemli taşıyıcılarındandır. İbrahim yurtdışında yaşayan Kıbrıslı Türkleri kaybetmemek adına İngilizce çalışmalar yaptığını beyan etmektedir. Gençlerin Türk olmaktan gurur duyduğunu ancak Türkçe bilmediklerini söylemektedir. Cezire Derneği de İngilizce bile olsa onlara kimliklerini tanıtmayı amaçlamaktadır. Zeynep'e göre İngilizce konuşmaları onları

\footnotetext{
${ }^{5}$ Harun'a göre Kıbrıslı Türklerin dışında Suudiler de bu durumdan rahatsız. Onlar da cenazelerini İngiltere'de toprağa vermemektedir. Ayrıca pandemiden dolayı Sri Lanka'da ölen coronalı Müslümanların krematoryum'da devlet eliyle yakıldığı gibi Londra'da böyle bir şey yaşanıp yaşanmadığını sordum. Harun da Londra'da böyle bir dedikodunun dolaştığını, akabinde Müslüman ve Yahudi örgütler birleşerek bu durumu parlementoya götürdüklerini söylemektedir. İngiliz yetkililerin ise 'Her ne kadar İngiliz vatandaşı olsanız da inancınız gereği böyle bir şeyin gerçekleşmesi mümkün değildir' diyerek onları teskin ettiğini söylemektedir. Sri Lanka'daki Müslüman cenazeler haberi için, bkz. Euronews, 2020.
} 
farklı k1lmaktadır. Zeynep’ten edindiğim bilgilerle kıyaslama yapmak gerekirse, diğer büyük camilerdeki din görevlileri yeterli seviyede İngilizce bilmemektedir. Türkiye'den gelen hocalar ise hem Kibris kültürüne hem de kullanılan dile yabancıdırlar. Bu yüzden kendilerinden biri olan Cezire Derneği bu alana farklı bir soluk getirmiştir.

\section{Sonuç}

$\mathrm{Bu}$ çalışma Londra'da yaşanan dini sosyal hareketliliği, misyonu tebliğ olmayan bir grup üzerinden gözlemlemektedir. Dernek, adıyla ve yaptığı çalışmalarla Kıbrıslı Türklerin dini kimliklerini ön plana çıkarmaktadır. Türkçeyi neredeyse konuşamayan yeni nesilleri kaybetmemek adına Kıbrıslı Müslüman Türk kimliğini İngilizce olsa bile yeni nesillere öğretmeyi amaçlamaktadır. Doğrudan tebliğ amac1 gütmeseler de yaptıkları faaliyetlerden de anlaşılacağı üzere Kıbrıslı Türk toplumu arasında İslami söylemi diri tutmaktadırlar. Ancak bunu yaparken dikkatli davranmaktadırlar. Derneğin hitap ettiği esas kitle Kıbrıslı Türklerdir. Seküler yaşama meyilli Kıbrıslı Türklerin derneğe karşı negatif bir tavır almalarını istememektedirler. Bu yüzden dernek, adanın tarihi ve kimliği üzerine çalışmalarını sürdürmektedir. Yapmış oldukları özverili çalışmalarla da diasporada söz sahibi olan İngiltere Kıbrıs Türk Dernekleri Konseyi tarafından onay görmektedirler. Kısıtlı imkânlara rağmen Kıbrıs'ın kuzeyindeki ve güneyindeki tarihi eserleri koruma azimleri ise takdire şayandır. Adanın 1400 yıldır Müslüman vatanı olduğu bilinciyle hareket eden dernek, seküler grupların baskılarına gögüs germektedir. Derneğin esas faaliyet noktası lobicilik olmasa da savunduğu özgün değerler açısından Kıbrıslı Türkleri ve KKTC'yi diğer milletlere tanıtmaktadır.

Londra'da yaşayan Türkçe konuşan topluluğun en eski üyeleri Kıbrıslı Türklerdir. Dördüncü ve beşinci nesil Kıbrıslı Türkler yetişmektedir. 90'lı yıllardan sonra doğan nesiller İngiliz toplumuna daha hızlı uyum sağlamaktadır. İlk nesillere göre yeni kuşak gençler Türkçeyi daha az bilmekte ya da bilmemektedir. Bu durum gençler arasında kimlik arayışlarına neden olmaktadır. Genç nesiller için dilini, dinini, örfünü tanıtacak mekânların yok denecek kadar az oluşu toplum için bir buhran oluşturmaktadır. Bu tarz buhranların üstesinden gelebilmek için de Cezire Derneği gibi kendi içlerinden gelen, toplumun kültürünü örfünü tanıyan, İngilizce konuşabilen sivil toplum kuruluşlarına ihtiyaç vardır.

Pandemi sürecindeki artan popülerlik neticesinde, ilerleyen süreçlerde Londra'da yaşayan Kıbrıslı Türkler arasında daha fazla tanınır hale geleceklerine şüphe yoktur. Fiziki mekânların olmayışı ve maddi gelirlerinin kısıtlı olması onlar için dezavantajlar oluşturmaktadır. Dernek siber uzam ortamında ise sosyal medya ve iletişim araçlarıyla güçlü bir şekilde var olmaktadır. Bu derneğin var olma ihtiyacı bile İngiltere'de yaşayan Kıbrıslı Türkler için dini bir hareketliliğin göstergesidir.

\section{Kaynakça}

Atay, Tayfun (2006). Türkler, Kürtler, Klbrislllar-İngiltere'de Türkçe Yaşamak, Dipnot Yayınları, Ankara.

Ateşin, Hüseyin Mehmet (1996). Kıbrıs'ta İslami Kimlik Davası, Marifet Yayınları, İstanbul. 
Bauman, Zygmunt (2019). Akışkan Modernite, Can Sanat Yayınları, İstanbul.

Cezire Derneği, t.y. http://cezire.org/ (Erişim Tarihi: 29.05.2020).

Cezire Derneği, 2020. http://cezire.org/2020/02/19/we-did-it/ (Erişim Tarihi: 29.05.2020).

Coştu, Yakup (2018). Ingiltere'de Türkler-Dinsel Yapı ve Organizasyonlar, Araştırma Yayınları, Ankara.

Çelik, Celaleddin (2005). İsim Kültürü ve Din, Çizgi Kitabevi, Konya.

Çelik, Celaleddin (2017). "Toplumsal Hafizanın İnşâsında İsimler”, Sosyoloji Divanı, Cilt 5, Say1 10, s. 63-75.

Dereli, Mustafa Derviş (2018). Dini Kimliklerin Sosyal Medyada Akışkanlaşması: Siber-etnografik Bir Araştırma, Erciyes Üniversitesi Sosyal Bilimler Enstitüsü Yayınlanmamış Doktora Tezi, Kayseri.

Dereli, Mustafa Derviş (2019). "Dinî Kimliklerin Siber Uzamda Akışkanlaşması", Insan \& Toplum Dergisi, Cilt 9, Sayı Mart, s. 85-116.

Devellioğlu, Ferit (2008). Osmanlıca-Türkçe Ansiklopedik Lûgat, (25. baskı), Aydın Kitabevi Yayınları, Ankara.

Dönmezer, Sulhi (1994). Toplumbilim, (11. bask1), Beta Yayınları, İstanbul.

Euronews, 2020. https://tr.euronews.com/2020/05/15/sri-lanka-da-covid-19-danolen-muslumanlar-n-cesetlerinin-yak-lmamas-icin-girisim (Erişim Tarihi: 20.05.2020).

Fichter, Joseph. (2011). Sosyoloji Nedir, (Çev. Nilgün Çelebi), Anı Yayıncılık, Ankara.

Gökdemir, Gönül (2006). "İngiltere'de Yaşayan Türklerin Ana Kültüre Bağl1lı̆̆ında İletişim Araçlarının Folkloristik Bağlamdaki İşlevi”, Türkbilig, Cilt 7, Say1 12, s. 173-184.

Gökdemir Reyhanoğlu, Gönül (2014). "İngiltere'de Yaşayan Kıbrıslı Türklerin Kültürel Belleklerini Koruma ve Aktarım Bağlamları", Mustafa Kemal Üniversitesi Sosyal Bilimler Enstitüsü Dergisi, Cilt 11, Say1 27, s. 1-14.

Hervieu-Leger, Daniele (2009). Sekülerleşme, Gelenek ve Dindarlığın Yeni Şekilleri: Bazı Teorik Öneriler, (Çev. Halil Aydınalp, s. 109-124), Din Sosyolojisi Klasik ve Çağdaş Yaklaşımlar, (Dü. Bünyamin Solmaz, İhsan Çapçıŏlu), (2. baskı), Çizgi Kitabevi, Konya.

İbn Haldun (2018). Mukaddime, (Çev. Süleyman Uludağ), (18. bask1), Dergah Yayınları, İstanbul.

Kibrıs Gazetesi, 2020. https://www.kibrisgazetesi.com/kibris/2-aylik-bekleyis-sonbuldu-h90645.html (Erişim Tarihi: 07.06.2020).

Kirman, Mehmet Ali (2004). Din Sosyolojisi Terimleri Sözlüğü, Rağbet Yayınları, İstanbul.

KKTC Londra Temsilciliği, t.y. https://londra.mfa.gov.ct.tr/temsilcilik/tarihce/ (Erişim Tarihi: 30.05.2020). 
Maden, Fahri (2015). "Kıbrıs'ta Bektaşilik ve Bektaşi Tekkeleri”, Alevilik Araştırmaları Dergisi, Cilt 5, Sayı 10, s. 89-142.

Punch, Keith (2005). Sosyal Araştırmalara Giriş, (Çev. Dursun Bayrak, H. Bader Arslan, Zeynep Akyüz ), Siyasal Kitabevi, Ankara.

Sezgin, İsmail (2019). Kıbrıslı Türklerin Dini Yaşayışları Üzerine Karşılaştırmalı Bir Çalışma (Güzelyurt Örneği), Necmettin Erbakan Üniversitesi Sosyal Bilimler Enstitüsü Yayınlanmamış Yüksek Lisans Tezi, Konya.

Şentürk, Recep (2004). Yeni Din Sosyolojileri, Gelenek Yayınc1lık, İstanbul.

T-wine, 2018. http://www.t-vine.com/europes-forgotten-greek-muslims-still-suffer120-years-after-exile/ (Erişim Tarihi: 08.06.2020).

Uysal, Ahmet (2016). "Londra'daki Türklere Ait Toplumsal ve Kültürel Organizasyonlar", Uluslararası Sosyal Araştırmalar Dergisi, Cilt 9, Sayı 47, s. 429-440. 